\title{
Seasonal variation in sedimentary amino acids and the association of organic matter with mineral surfaces in a sandy eelgrass meadow
}

\author{
Benjamin A. S. Van Mooy*, Richard G. Keil \\ School of Oceanography, University of Washington, Box 355351, Seattle, Washington 98195-5351, USA
}

\begin{abstract}
The eelgrass meadow in Padilla Bay, Washington, has a seasonal cycle of production that is dependent on nutrient remineralization from sedimentary organic matter. We observed seasonal differences in the loading of organic carbon (OC) on mineral surface area ranging from $0.90 \pm 0.30 \mathrm{~g} \mathrm{C} \mathrm{m}^{-2}$, which is typical for coastal sediments, to $2.72 \pm 0.49$. There were also changes in organic matter quality as indicated by amino acid analyses. The fraction of OC composed of amino acids changed from 0.03 to 0.12 during the same time period. The molecular distribution of amino acids also varied seasonally as indicated by changes in the amino acid degradation index. Bacterial numbers were constant throughout the year, and we attribute changes in sedimentary organic matter primarily to changes in input from benthic algae.
\end{abstract}

KEY WORDS: Eelgrass · Intertidal sediments · Organic carbon · Mineral surface area · Amino acids

\section{INTRODUCTION}

The productivity of eelgrass meadows is intimately linked to the microbial cycling of organic matter in the sediments. Therefore, as eelgrasses undergo seasonal cycles of production, one may expect to observe concomitant seasonal changes in the distribution and reactivity of sedimentary organic matter. However, organic matter may be protected from microbial degradation by interaction with mineral surfaces. Thus, we hypothesize that the seasonal cycle of production in an eelgrass meadow is reflected in the association of organic matter with mineral surfaces.

Eelgrasses trap fine-grained suspended particles by altering the hydraulic regime of their environment (Fonseca et al. 1982) and retain organic matter produced by the eelgrasses themselves and by other photosynthetic organisms such as epiphytes and benthic algae (Thom \& Albright 1990, Hemminga et al. 1991). As a byproduct of organic matter degradation,

\footnotetext{
*E-mail: bvm@ocean.washington.edu
}

heterotrophic organisms release inorganic nitrogen and other nutrients to sediment porewaters (Short 1987, Harrison 1989, Hemminga et al. 1991). Sedimentary inorganic nitrogen is taken up by eelgrass roots (or possibly leaves; Hemminga et al. 1994) and supplies a significant fraction of that needed for production (Hemminga et al. 1991, Pedersen \& Borum 1993).

Eelgrass production in Padilla Bay, Washington, undergoes a strong seasonal cycle. Zostera marina dominates this sheltered, intertidal bay (Bulthuis 1995) and eelgrass biomass peaks in late summer at ca. $150 \mathrm{~g} \mathrm{~m}^{-2}$ and decreases to only ca $10 \mathrm{~g} \mathrm{~m}^{-2}$ in winter (Thom 1990). In the spring, growth is triggered by increased solar radiation, but overlying waters are bereft of dissolved inorganic nutrients when production peaks in early summer (Thom \& Albright 1990). Epiphytes grow rapidly on the eelgrass blades and efficiently hinder the transfer of inorganic nitrogen from overlying water into eelgrass blades; hence, eelgrass production is heavily dependent on the remineralization of ammonia from organic matter by sedimentary microorganisms during peak production (Williams \& Ruckelshaus 1993). 
Organic matter, however, may be protected from microbial attack by adsorption to mineral surfaces in sediment. Organic carbon (OC) concentration is correlated with mineral surface area (SA) in marine and estuarine sediments (Mayer et al. 1985, Mayer 1994, Hedges \& Keil 1995, 1999, Keil et al. 1997). Mayer (1994) observed the loading of organic matter in typical, non-vegetated coastal marine sediments to be quite consistent, with a mean loading of $0.86 \mathrm{mg}$ of $\mathrm{OC}$ per square meter of mineral SA $\left(\mathrm{mg} \mathrm{C} \mathrm{m}^{-2}\right)$. Therefore, coastal marine silts and clays, which have higher surface area by mass than sands, are expected to be richer in organic matter than sands. Eelgrasses, by trapping fine-grained particles, may enhance the organic matter concentration of the sediment in which they are living.

Amino acids are the most labile class of biochemicals and are a critical substrate for microbial growth in marine environments (Keil et al. 2000). These nitrogen-rich compounds compose the bulk of organic matter that may be characterized at the molecular level in marine sediments (Wakeham et al. 1997). The relative molecular distribution of amino acids changes as the microbial degradation of organic matter proceeds, and this observation has been used to assess the extent of degradation of sedimentary organic matter (Dauwe et al. 1999, Keil et al. 2000). As such, studying the amino acids in eelgrass sediments may provide additional insight regarding the availability of organic matter for microbial degradation.

\section{MATERIALS AND METHODS}

Padilla Bay contains one of the largest contiguous eelgrass meadows on the Pacific coast of North America (Bulthuis 1995) and a $2 \mathrm{~km}$ transect (from $48^{\circ} 34.39^{\prime} \mathrm{N}$, $122^{\circ} 32.36^{\prime} \mathrm{W}$ to $48^{\circ} 34.11^{\prime} \mathrm{N}, 122^{\circ} 31.79^{\prime} \mathrm{W}$ ) parallel to the shoreline on the north end of the bay was chosen as our field location. A brief visual survey of the intertidal meadow indicated that there were no large differences in sediment texture or eelgrass density along the transect. Sediment sampling was conducted during low tide when most areas were in 5 to $10 \mathrm{~cm}$ of water in August 1999 (summer), and January (winter), March (early spring), and June 2000 (late spring). Samples were collected at 10 sites along the transect (identified by GPS) and additional samples were randomly collected at both ends of the transect. Small cores extending roughly $10 \mathrm{~cm}$ into the sediment were taken using a $20 \mathrm{ml}$ plastic syringe with the end cut off. The cores were immediately transferred into sterile plastic tubes and frozen at $-70^{\circ} \mathrm{C}$ within an hour of sampling. Samples were stored in the laboratory at $-20^{\circ} \mathrm{C}$.
For sediment surface area and organic analyses, sediments were thawed, homogenized by stirring, and placed in a centrifuge tube with 3 volumes of organicfree water to remove salts. Samples were centrifuged at $5000 \times g$ for $15 \mathrm{~min}$ to retain sediment and $\mathrm{OC}$ and the clear supernatant was discarded. The rinsing procedure was repeated 2 more times. Prior to being dried to constant weight at $60^{\circ} \mathrm{C}$, large organic debris (wood, roots, etc.) was picked from the sediment and discarded. The sediments were then analyzed in triplicate for OC and total nitrogen (TN), and inorganic carbon as described by Hedges \& Stern (1984) using a Carlo Erba CHN analyzer. For surface area, the sediment samples were combusted at $350^{\circ} \mathrm{C}$ for $12 \mathrm{~h}$ and surface areas were determined in triplicate by the BET (Brunauer-Emmett-Teller) method as described by Keil et al. (1994).

Bacterial counts were obtained as described by Schmidt et al. (1998) from 2 randomly chosen stations from each season. Cores were taken with sterile $5 \mathrm{ml}$ plastic syringes with the tips cut off, placed in sterile plastic tubes, and diluted to $30 \mathrm{ml}$ with filtered $(0.2 \mu \mathrm{m})$ seawater. Formaldehyde was then added to a final concentration of $2 \%$ and samples were stored in the dark at $4^{\circ} \mathrm{C}$ for no longer than $1 \mathrm{yr}$ before counting. Following brief sonication to detach bacteria from the sediments, the samples were stained with acridine orange (AO) and filtered onto black polycarbonate filters. Bacteria were then stained with diamidino-2phenylindole (DAPI) and routine counts were made by switching between optical filters for AO and DAPI.

Sedimentary amino acids were analyzed in duplicate exactly as described by Van Mooy et al. (2002) using a slightly modified technique of Cowie \& Hedges (1992) from the same locations chosen for bacterial counts. Eelgrass blades, harvested in late spring and cleaned by gently scraping with a spatula, were also analyzed. Samples were spiked with charge-matched recovery standards and hydrolyzed with $6 \mathrm{~N} \mathrm{HCl}$ under $\mathrm{N}_{2}$ for $70 \mathrm{~min}$ at $150^{\circ} \mathrm{C}$. Hydrolysates were neutralized with $0.2 \mathrm{~N} \mathrm{H}_{3} \mathrm{BO}_{3}$ buffer ( $\left.\mathrm{pH}=9.5\right)$, dried under vacuum, and then reconstituted in water and the $\mathrm{pH}$ adjusted to between 8 and 8.5 with buffer. Fluorescent (o-phthaldialdehyde) derivatives of primary amines were injected into a Waters HPLC system, detected by fluorescence, and quantified by normalizing peak areas to response factors for individual amino acids determined from standard mixtures. Then the amino acids were further normalized to the recovery of the chargematched standards. The total quantity of amino acids in particles is expressed as the fraction of $\mathrm{OC}$ that is composed of carbon from amino acids (AA/OC $\times 100)$. Dauwe et al. (1999) computed a degradation index (DI), based on the distribution of the 14 commonly analyzed amino acids (lysine and non-protein amino acids 
were not included) in organic matter from other marine settings. The DI essentially distills the subtle and complex changes in amino acid distributions into 1 value that decreases with progress along the early diagenetic continuum and values range from 1.5 for rapidly decaying phytoplankton to -2.2 for an oxidized turbidite sediment where organic matter was stable on millennial timescales. We calculated the DI from our amino acid distributions using the equations of Dauwe et al. (1999) as they have described.

\section{RESULTS}

Padilla Bay sediments were relatively poor in organic matter and had low SA by mass (Table 1). The OC content of the sediments ranged from 1 to $8 \mathrm{mgC}$ (g sediment) ${ }^{-1}$ and mean values varied throughout the year (ANOVA; $p=0.052$ ). Although inorganic carbon was occasionally detected, the vast majority of samples contained none. The TN content of the sediments ranged from 0.2 to $1.0 \mathrm{mgN}$ (g sediment) ${ }^{-1}$. $\mathrm{C} / \mathrm{N}$ ratio was generally around 10 and regressions of OC versus TN from each sampling interval were homogeneous ( $p=0.976)$. However, an ANCOVA revealed that there were changes in TN not directly attributable to
Table 1. Geochemical data for sediments (mean $\pm 1 \mathrm{SD})$ and parameters for the regressions in Fig. 1 (coefficient $\pm 1 \mathrm{SE}$ ). Units: OC (mgC [gsediment $^{-1}$ ), TN (mgN [gsediment $\left.{ }^{-1}\right)$, C/N ratio (unitless, atomic), SA $\left(\mathrm{m}^{2}\right.$ [g sediment $\left.^{-1}\right)$. OC/SA is defined by the slope of the regressions

\begin{tabular}{|lcccc|}
\hline & Summer & Winter & Early spring & Late spring \\
\hline Sediments & & & & \\
OC & $3.7 \pm 0.9$ & $4.5 \pm 1.0$ & $4.4 \pm 3.3$ & $4.7 \pm 1.5$ \\
TN & $0.44 \pm 0.11$ & $0.60 \pm 0.27$ & $0.57 \pm 0.47$ & $0.53 \pm 0.17$ \\
C/N & $9.8 \pm 0.6$ & $9.9 \pm 0.9$ & $9.0 \pm 1.1$ & $10.3 \pm 0.7$ \\
SA & $1.9 \pm 0.4$ & $2.6 \pm 0.8$ & $1.8 \pm 0.5$ & $1.8 \pm 0.6$ \\
$\mathrm{n}$ & 20 & 12 & 11 & 16 \\
& & & & \\
Regressions & & & & \\
OC vs SA & & & & \\
Slope & $1.68 \pm 0.27$ & $0.90 \pm 0.30$ & $2.72 \pm 0.49$ & $2.01 \pm 0.45$ \\
$\mathrm{R}^{2}$ & 0.679 & 0.471 & 0.770 & 0.590 \\
$\mathrm{P}$ & $<0.0001$ & 0.0138 & 0.0004 & 0.0005 \\
\hline
\end{tabular}

changes in OC $(p=0.026)$. Eelgrass had a $\mathrm{C} / \mathrm{N}$ ratio of 14. Mineral SA ranged from 1 to $3 \mathrm{~m}^{2}$ (g sediment) $)^{-1}$ and was invariant throughout the year (ANOVA; $p=0.523)$.

There was a strong correlation between OC content and mineral SA and these data showed seasonal variation (Fig. 1, Table 1). The slope of OC versus SA indicates the loading of $\mathrm{OC}$ on mineral SA and has the units $\mathrm{mg} \mathrm{C} \mathrm{m}^{-2}$. The slope was highest in early spring
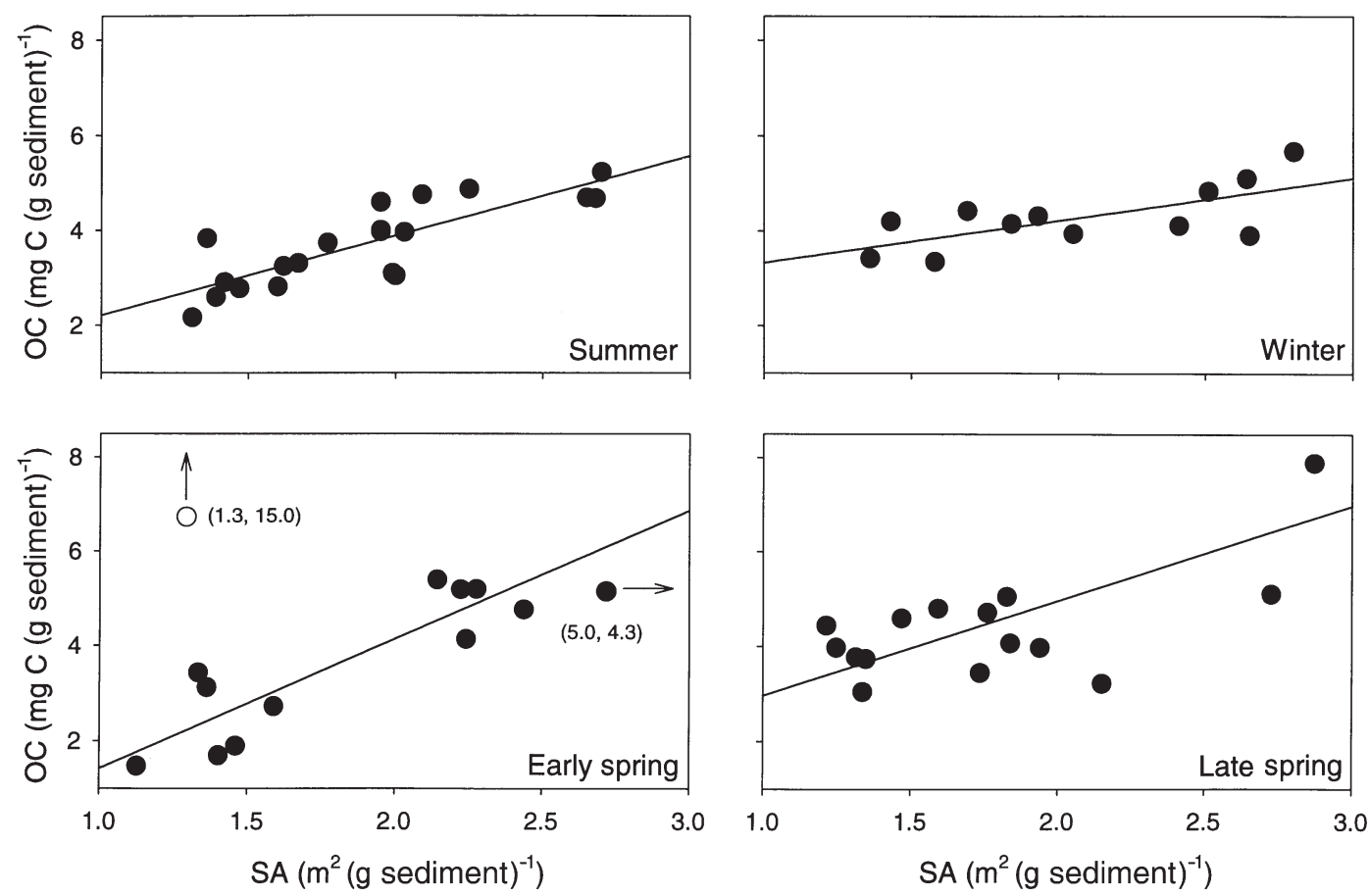

Fig. 1. Plots of organic carbon (OC) versus mineral surface area (SA) for the 4 sampling intervals. In early spring, there were 2 outliers and their coordinates are indicated. The point indicated by the empty circle was one of the samples for this time point that were chosen for amino acid analysis. All other samples chosen for amino acid analysis lie within the typical range of OC and SA 
with progressively lower values in the late spring, summer, and winter. At each sampling interval the correlation was significant, though in early spring there were 2 outliers that were not included in the regression. The regressions were tested for homogeneity and the $F$-statistic indicated that the slopes were not homogeneous $(p=0.0448)$. Hence, the loading of organic matter on mineral surfaces differed between the sampling intervals. While an ANCOVA is not strictly appropriate for regressions with different slopes, particularly for those without the same number of samples (Lowry 2001), the highly significant $F$-statistic $(\mathrm{p}=0.001)$ suggests differences in OC between sampling intervals that were independent of any attendant differences in SA.

The abundance of bacteria remained constant throughout the year (Fig. 2A). Counts were an order of magnitude lower than in muds from Puget Sound (Schmidt et al. 1998), but were reasonable considering the low SA of the sands we studied (DeFlaun \& Mayer 1983, Yamamoto \& Lopez 1985).

Amino acids composed a relatively small fraction of the OC in the sedimentary organic matter of Padilla Bay sands, except in spring (Fig. 2B). One of the samples selected for amino acid analysis in early spring was one of the outliers (see Fig. 1): it was substantially 'over-loaded' with $\mathrm{OC}$ and had a $\mathrm{C} / \mathrm{N}$ ratio of 7.7, which suggested contamination from fresh algal biomass. Not including this outlier, the seasonal record of AA/OC ratio showed significant variation (ANOVA; $\mathrm{p}<0.001$ ). The distributions of individual protein amino acids (data not shown) were typical for intertidal muds (Mayer et al. 1985). The DI of the sediments changed during the year $\left(\mathrm{ANOVA}_{i} \mathrm{p}=0.002\right)$ and thus reflected changes in the quality of sedimentary organic matter (Fig. 2C). The AA/OC ratio of eelgrass was $0.20 \pm 0.02$ and the molecular distribution of amino acids agreed well with those reported by Pedersen et al. (1999) for Zostera marina. Eelgrass had a DI of $1.8 \pm 0.1$.

\section{DISCUSSION}

The eelgrass meadow in Padilla Bay undergoes a strong seasonal cycle of production, and we have observed concomitant changes in the organic geochemistry of the sediments at this location. These changes were manifested both in changes in the loading of organic matter on mineral surfaces, and in the character of organic matter as indicated by the concentration and composition of amino acids.

Organic matter associated with mineral surfaces undergoes net degradation during the autumn as evidenced by changes in the slope of OC versus SA. In late summer, the loading of $\mathrm{OC}$ on mineral surfaces
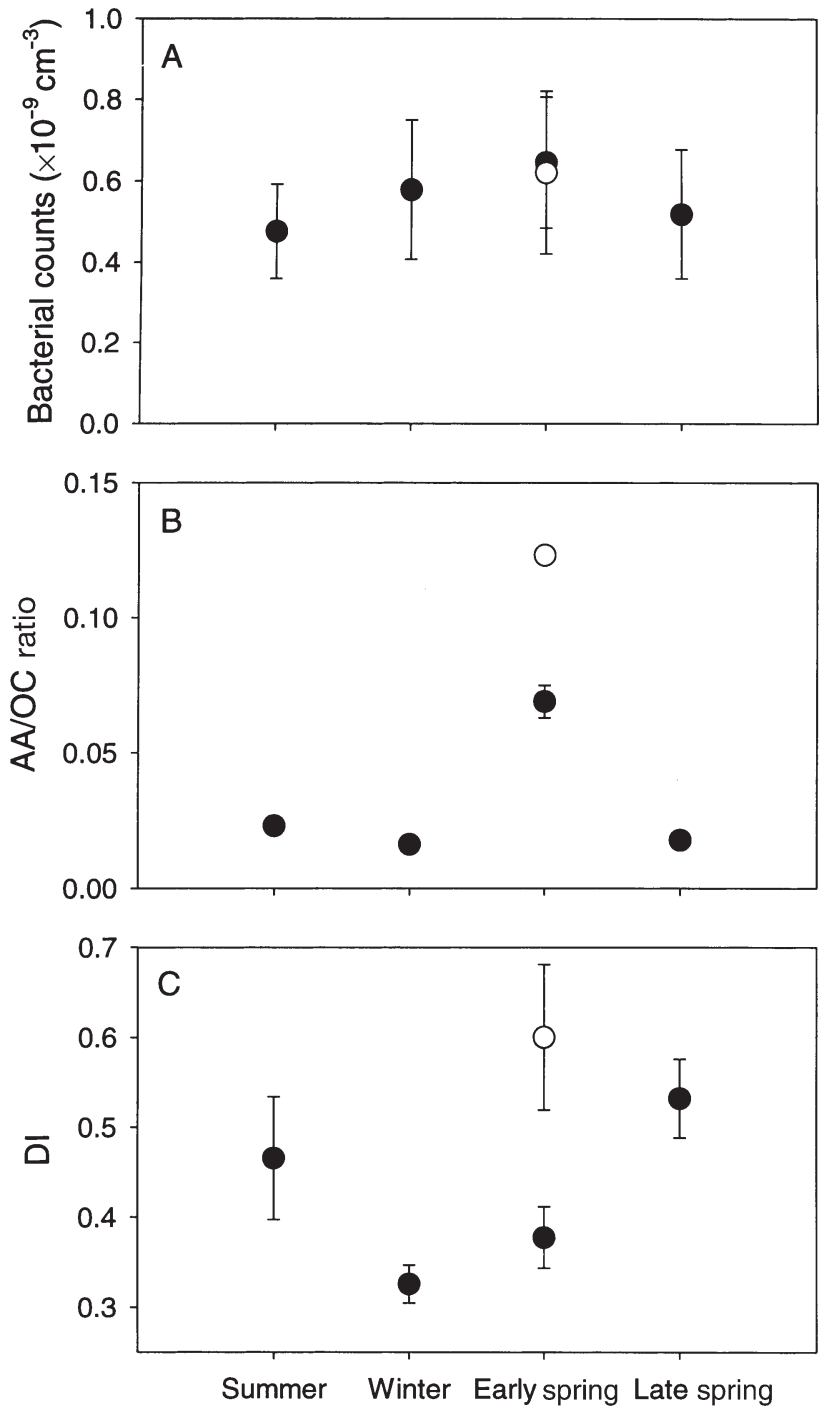

Fig. 2. Seasonal times series of (A) bacterial counts, (B) amino acid content of organic matter, and $(\mathrm{C})$ the degradation index (DI). Empty circles indicate the outlying sample from Fig. 1. For summer, $\mathrm{n}=4$; winter, $\mathrm{n}=4$; early spring, $\mathrm{n}=2$ and 2 ; and late spring, $\mathrm{n}=4$. Data are mean $\pm 1 \mathrm{SD}$

was $1.68 \pm 0.27 \mathrm{mgC} \mathrm{m}^{-2}$, which is higher than the typical coastal marine loading of $0.86 \mathrm{mg} \mathrm{C} \mathrm{m}^{-2}$, indicating that the sediments may have been slightly 'overloaded' with organic matter. However, by winter, the loading of OC on mineral surfaces had decreased substantially to the typical coastal marine loading value. This observation is analogous to the finding that shelf sediments from the sediment water interface had anomalously high loading of organic matter, but after burial and successive microbial attack the sediments converged down-core on the typical coastal marine loading (Mayer 1994). Mayer (1994) suggested that the typical coastal marine value represented a 'monolayerequivalent' loading of degradation-resistant organic 
matter on mineral surfaces. Keil et al. (1994) demonstrated that the organic matter from sediments of typical coastal marine loading was highly susceptible to microbial degradation if de-sorbed from the sediments. Since then it has been suggested that organic matter is not uniformly loaded on sediments, but may be concentrated in mesopores (Mayer 1999) or at mineralmineral contact points (Ransom et al. 1999) surfaces, thereby protecting it from enzymatic attack by microorganisms (Mayer 1999). Our observations from Padilla Bay support a model where organic matter is tightly associated with mineral surfaces throughout the year, but only a fraction of the 'overloaded' OC on mineral surfaces is ultimately protected from microbial attack, perhaps that which is adsorbed in sediment pores.

In early spring, the loading of organic matter on mineral surfaces became substantially greater than that typical for coastal marine sediments. Sediments in Padilla Bay are bereft of eelgrass cover in early spring, and are exposed to the seasonally increasing solar radiation; with an abundant supply of nitrogen from the sediments and the water column (Thom \& Albright 1990) conditions are ideal for the production of organic matter by benthic algae. Thom (1990) observed that sediment chlorophyll concentrations in Padilla Bay peaked in early spring, before eelgrass production resumed. Organic carbon produced by benthic algae in sandy intertidal sediments may be rapidly transferred to bacteria (Middelburg et al. 2000), but our observations indicate that any input of OC from benthic algae in Padilla Bay did not lead to an increase in bacterial abundance. And thus, we suspect that the substantial 'over-loading' of organic matter in early spring originated primarily from photosynthetic production within the surface sediments themselves and not from increased active bacterial biomass.

By late spring, the loading of organic matter in the eelgrass meadow sediments approached that of the previous summer. Eelgrass cover increases rapidly in late spring (Thom 1990), and throughout the growth season Zostera marina may consistently exude as much as $4 \%$ of total photosynthetic production as dissolved OC into the sediments (Blaabjerg et al. 1998). Dissolved organic matter of seagrass origin is amenable to microbial degradation (Blaabjerg et al. 1998), and the balance between supply and microbial degradation of this material was most probably responsible for the consistent, but slight 'over-loading', of organic matter on mineral surfaces observed throughout the summer.

The amino acid data also support the possibility of a seasonal influx of organic matter in the early spring. Generally, amino acids composed a relatively small fraction of organic matter, suggesting that organic matter sustained proteolytic attack by organisms in the sediment. However in early spring, concentrations approached those observed in other coastal sediments (Keil et al. 2000), suggesting that influx exceeded degradation substantially. The spring peak in amino acid-rich biomass suggests that benthic algal production may distribute a substantial quantity of labile organic matter throughout the sediment community prior to the bloom in eelgrass production. The ANCOVA of TN and OC supports this observation of changing contributions of amino acids to organic matter.

The DI values were typical for the coastal sediments observed by Dauwe et al. (1999) and suggest that the organic matter had the potential to be turned over rapidly. The values also showed seasonal variation: the DI decreased in the autumn, suggesting that the organic matter became less reactive and then increased in the spring as the eelgrass meadow became more productive. It was expected that the outlier (in Fig. 2) that was contaminated with fresh algal biomass would have a high DI, but we are puzzled that the DI of the other sample, while greater than in winter, is relatively low despite its high abundance of amino acids. The DI was highest in late spring and summer when eelgrass production was at its maximum, which suggests that sedimentary organic matter is cycled most rapidly when eelgrasses depend most critically on sedimentary sources of nitrogen. These high DI values could also indicate the presence of OC of eelgrass origin during this period.

In summary, the data indicate that the loading of organic matter on mineral surfaces varied seasonally with the production of organic matter from photosynthetic organisms. What is particularly striking is the strength of the OC/SA relationship at each sampling interval; despite heterogeneity in the sediments that were sampled, the concentration of OC was nearly uniform with respect to SA. Thus, it appears that while meadow-scale photosynthetic processes vary the influx of organic matter to the sediment, mineral SA affects the capacity of the sediment to retain OC on the centimeter scale by regulating the availability of $\mathrm{OC}$ for degradation.

Acknowledgements. We are grateful to undergraduates J. Caldwell, J. Crowley, and C. Louis for performing many of the analyses included in this paper as a part of their senior theses and summer internships. We sincerely thank J. Schmidt for contributing bacterial counts. J. Hedges, S. Riggs and D. Bulthuis contributed critical logistical and scientific support for which we are very grateful. T. Van Mooy graciously provided field assistance late one January evening during a snowstorm. The manuscript benefited from input by 3 anonymous reviewers, one of whom suggested many detailed improvements. This work was supported by the NOAA Office of Ocean and Coastal Resource Management through the Washington State Department of Ecology, and the National Science Foundation (OCE9711792 to R.G.K.). 


\section{LITERATURE CITED}

Blaabjerg V, Mouritsen KN, Finster K (1998) Diel cycles of sulphate reduction rates in sediments of a Zostera marina bed (Denmark). Aquat Microb Ecol 15:97-102

Bulthuis DA (1995) Distribution of seagrasses in a North Puget Sound estuary: Padilla Bay, Washington, USA. Aquat Bot 50:99-105

Cowie GL, Hedges JI (1992) Improved amino acid quantification in environmental samples: charge-matched recovery standards and reduced analysis time. Mar Chem 37: 223-238

Dauwe B, Middelburg JJ, Herman, PMJ, Heip CHR (1999) Linking diagenetic alteration of amino acids and bulk organic matter reactivity. Limnol Oceanogr 44: 1809-1814

DeFlaun MF, Mayer, LM (1983) Relationships between bacteria and grain surfaces in intertidal sediments. Limnol Oceanogr 28:873-881

Fonseca MS, Fisher JS, Zieman JC, Thayer GW (1982) Influence of seagrass, Zostera marine L., on current flow. Estuar Coast Shelf Sci 15:351-364

Harrison PG (1989) Detrital processing in seagrass systems: a review of factors affecting decay rates, remineralization, and detritivory. Aquat Bot 23:263-288

Hedges JI, Keil RG (1995) Sedimentary organic matter preservation: an assessment and speculative synthesis. Mar Chem 49:81-115

Hedges JI, Keil RG (1999) Organic geochemical perspectives on estuarine processes: sorption reaction and consequences. Mar Chem 65:55-65

Hedges JI, Stern JH (1984) Carbon and nitrogen determinations of carbonate-containing solids. Limnol Oceanogr 29: 657-663

Hemminga MA, Harrison PG, van Lent F (1991) The balance of nutrient losses and gains in seagrass meadows. Mar Ecol Prog Ser 71:85-96

Hemminga MA, Koutstaal BP, van Soelen J, Merks AGA (1994) The nitrogen supply to intertidal eelgrass (Zostera marina). Mar Biol 118:223-227

Keil RG, Montluçon DB, Prahl FG, Hedges JI (1994) Sorptive preservation of labile organic matter in marine sediments. Nature 370:549-551

Keil RG, Mayer LM, Quay PD, Richey JE, Hedges JI (1997) Loss of organic matter from riverine particles in deltas. Geochim Cosmochim Acta 61:1507-1511

Keil RG, Tsamakis E, Hedges JI (2000) Early diagenesis or particulate amino acids in marine sediments. In: Goodfriend GA, Collins MJ, Fogel ML, Macko SA, Wehmiller JF (eds) Perspectives in amino acid and protein chemistry. Oxford University Press, New York, p 69-82

Lowry R (2001) Concepts and applications of inferential sta-

Editorial responsibility: Otto Kinne (Editor),

Oldendorf/Luhe, Germany tistics. Web publication: http://faculty.vassar.edu/ lowry/ webtext.html. Vasser College, Pooghkeepsie, New York

Mayer LM (1994) Relationships between mineral surfaces and organic carbon concentrations in soils and sediments. Chem Geol 114:347-363

Mayer LM (1999) Extent of coverage of mineral surface by organic matter in marine sediments. Geochim Cosmochim Acta 63:207-215

Mayer LM, Rahaim PT, Guerin W, Macko SA, Watling L, Anderson FE (1985) Biological and granulometric controls on sedimentary organic matter of an intertidal mudflat. Estuar Coast Shelf Sci 20:491-503

Middelburg JJ, Barranguet C, Boschker HTS, Herman PMJ, Moens T, Heip CHR (2000) The fate of intertidal microphytobenthos carbon: an in situ ${ }^{13} \mathrm{C}$-labelling study. Limnol Oceanogr 45:1224-1234

Pedersen AGU, Bernsten J, Lomstein BA (1999) The effect of eelgrass decomposition on sediment carbon and nitrogen cycling: a controlled laboratory experiment. Limnol Oceanogr 44:1978-1992

Pedersen MF, Borum J (1993) An annual nitrogen budget for a seagrass Zostera marina population. Mar Ecol Prog Ser 101:169-177

Ransom B, Bennett RH, Baerwald R, Hulbert MH, Burkett PJ (1999) In situ conditions and interactions between microbes and minerals in fine-grained marine sediments: a TEM perspective. Am Mineralogist 84:183-192

Schmidt JL, Deming JW, Jumars PA, Keil RG (1998) Constancy of bacterial abundance in surficial marine sediments. Limnol Oceanogr 43:976-982

Short FT (1987) Effects of sediment nutrients on seagrasses: literature review and mesocosm experiment. Aquat Bot 27:41-57

Thom RM (1990) Spatial and temporal patterns in plant standing stock and primary production in a temperate seagrass system. Bot Mar 33:497-510

Thom RM, Albright RG (1990) Dynamics of benthic vegetation standing-stock, irradiance, and water properties in central Puget Sound. Mar Biol 104:129-141

Van Mooy BAS, Keil RG, Devol AH (2002) Impact of suboxia on sinking particulate organic carbon: enhanced carbon flux and preferential degradation of amino acids via denitrification. Geochim Cosmochim Acta 66:457-465

Wakeham SG, Lee C, Hedges J, Hernes PJ, Peterson ML (1997) Molecular indicators of diagenetic status in marine organic matter. Geochim Cosmochim Acta 61:5363-5369

Williams SL, Ruckelshaus MH (1993) Effects of nitrogen availability and herbivory on eelgrass (Zostera marina) and epiphytes. Ecology 74:904-918

Yamamoto N, Lopez G (1985) Bacterial abundance in relation to surface area and organic content of marine sediments. J Exp Mar Biol Ecol 90:209-210

Submitted: November 22, 2000; Accepted: June 28, 2001

Proofs received from author(s): February 1, 2002 